Journal of Maternal and Child Health (2016), 1(4): 214-219

https://doi.org/10.26911/thejmch.2016.01.04.02

\title{
Association Between Pregnant Woman Class and Pregnancy Complication in Tegal District, Central Java
}

\author{
Siti Maryani'), Supriyadi Hari Respati²), Okid Parama Astirin3) \\ 1)Academy of Midwifery Siti Fatimah, Slawi, Central Java \\ 2)Department of Obstetrics and Gynecology, Dr. Moewardi Hospital, Surakarta \\ 3)Faculty of Mathematics and Natural Sciences, Universitas Sebelas Maret
}

\begin{abstract}
Background: Maternal mortality amounted to 33 cases in Tegal, Central Java, in 2015. The leading cause of maternal mortality rate in Indonesia was obstetric complication, i.e $46.8 \%$. Pregnancy complication may be affected by maternal age, parity, education, and maternal employment status. Various efforts have been implemented by the government to reduce maternal mortality rate, including pregnant woman class. The objective of the pregnant mother class is to increase maternal knowledge in risk factor detection and to increase their willingness to use antenatal care. This study aimed to estimate the association between pregnant woman class and pregnancy complication, while controlling for confounding factors.

Subjects and Method: This was an analytical observational with case control design. This study was conducted at Pagerbarang, Pangkah and Dukuhwaru Health Centers, Tegal, Central Java. A total of 90 study subjects, consisting of 30 laboring women with complication and 60 without complication. The dependent variable was pregnancy complication. The independent variables were maternal age, parity, education, employment status, and participation in pregnant woman class. The data were collected by a set of questionnaire. The data on pregnancy complication was obtained from the obstetric record at the health center. The data were analyzed by multiple logistic regresion.

Results: Parity $\geq 3(\mathrm{OR}=3.47 ; 95 \% \mathrm{CI}=0.95$ to $12.69 ; \mathrm{p}=0.060)$ and maternal education $<$ senior high school $(\mathrm{OR}=8.58 ; 95 \% \mathrm{CI}=1.7$ to $43.33 ; \mathrm{p}=0.009)$ increased the risk of pregnancy complication. Maternal age 20 to 35 years $(\mathrm{OR}=0.26 ; 95 \% \mathrm{CI}=0.08$ to $0.81 ; \mathrm{p}=0.020)$, employed mother $(\mathrm{OR}=0.21 ; 95 \% \mathrm{CI}=0.06$ to $0.71 ; \mathrm{p}=0.012)$, and participation in pregnant woman class $(\mathrm{OR}=$ $0.35 ; 95 \% \mathrm{CI}=0.12$ to $1.05 ; \mathrm{p}=0.061$ ), decreased the risk of pregnancy complication.

Conclusion: Participation in pregnant woman class is associated with decreased risk of pregnancy complication. Parity $\geq 3$ and maternal education $<$ senior high school are associated with increased risk of pregnancy complication. Maternal age 20 to 35 years and employed mother are associated with decreased risk of pregnancy complication. It is suggested that pregnant women plan their pregnancy in order to prevent pregnancy complication.
\end{abstract}

Keywords: pregnant woman class, pregnancy complication.

\section{Correspondence :}

Siti Maryani. Academy of Midwifery Siti Fatimah, Slawi, Central Java. Mobile: 085741950488.

\section{BACKGROUND}

Complications which particularly occur before, during and after labor are hemorrhage, obstructed or prolonged labor, and infection due to trauma during labor (UNF$\mathrm{PA}$, 2004). Complication of labor is a condition that threatens maternal life or fetus because of the disorder as a direct result of pregnancy or labor such as hemorrhage, infection, pre-eclampsia/ eclampsia, prolonged/ obstructed labor, abortion, uterine rupture which need obstetric management without any plan previously (Ministry of Health, 1997).

The Maternal Mortality Rate of Central Java province in 2014 was 126.55 per 100.000 live births. It has increased com- 
pared to Maternal Mortality Rate in 2013 of 118.62 / 100,000 live births (Central Java Provincial Health Office, 2014). 57.95\% of Maternal Mortality Rate occurred during puerperium, 27\% occurred during pregnancy, and $\mathbf{1 5 . 0 5 \%}$ occurred during labor. Based on age groups, the percentage of highest incidence of maternal mortality were $62.02 \%$ in productive age (20-34 years), $30.52 \%$ in $>35$ years, and $7.45 \%$ in $<20$ years.

The causes of Maternal Mortality Rate in Central Java were hemorrhage (22.93\%), hypertension (26.44\%), circulatory system disorder (4.64\%), infection (3.66\%), and other causes (42.33\%). The most common cause of Maternal Mortality Rate and Infant Mortality Rate in Indonesia is obstetric complication (46.8\%).

Obstetric complication among others is affected by maternal reproductive status or commonly known as $4 \mathrm{~T}$ (too young, too old, too close, too often) (Central Java Provincial Health Office, 2014). Since 2010, the Government of Indonesia has held a pregnant woman class program at community health center level. Pregnant woman class is a facility for pregnant women which aim to learn together about health. One of the output indicators of pregnant woman class is the percentage of mothers who come to K4 (contacts at least 4 times during pregnancy). The higher percentage of $\mathrm{K}_{4}$ is expected to minimize the labor complication. Therefore, the maternal mortality rate can decrease (Health Department, 2009).

\begin{tabular}{l} 
SUBJECTS AND METHOD \\
\hline 1. Study Design \\
This was an analytical observational with \\
case control design. This study was conduc- \\
ted at Pangkah, Tegal District, Central Java.
\end{tabular}

\section{Population and Sampling}

There were 90 subjects of the study, consisting of 30 laboring women with complica- tion in case group and 60 without complication in case control. They were selected by purposive sampling technique.

\section{Study Variables}

The independent variables were maternal age, parity, education, employment status, and participation in pregnant woman class. The dependent variable was pregnancy complication.

\section{Study Instruments}

The instruments used in this study were a set of questionnaires, the maternal registration book in health center, and the attendance list of women who participated in pregnant woman class.

\section{Data Analysis}

Data processing was conducted by using univariate, bivariate, and multivariate analysis with multiple logistic regresion.

\section{RESULT}

The result of data distribution, bivariate, and multivariate analysis was showed in table 1, table 2, and table 3 .

Table 1. The frequency distribution of study variables of the association between pregnant woman class and complication of labor.

\begin{tabular}{|c|c|c|}
\hline Variable & $\bar{n}$ & $\%$ \\
\hline \multicolumn{3}{|l|}{ Maternal age } \\
\hline$<20$ or $\geq 35$ years old & 53 & 58.9 \\
\hline 20-35 years old & 37 & 41.1 \\
\hline \multicolumn{3}{|l|}{ Parity } \\
\hline$<3$ children & 31 & 34.4 \\
\hline$\geq 3$ children & 59 & 65.6 \\
\hline \multicolumn{3}{|l|}{ Education } \\
\hline$\geq$ Senior High School & 66 & 73.3 \\
\hline < Senior High School & 24 & 26.7 \\
\hline \multicolumn{3}{|l|}{ Employment status } \\
\hline Employee & 65 & 72.2 \\
\hline Housewife & 25 & 27.8 \\
\hline \multicolumn{3}{|c|}{ Participation in pregnant woman class } \\
\hline Participated & 48 & 53.3 \\
\hline Not participated & 42 & 46.7 \\
\hline \multicolumn{3}{|l|}{ Complication of labor } \\
\hline Yes & 30 & 33.3 \\
\hline No & 60 & 66.7 \\
\hline
\end{tabular}


Journal of Maternal and Child Health (2016), 1(4): 214-219

https://doi.org/10.26911/thejmch.2016.01.04.02

Table 2. The result of bivariate analysis of study variables of the association between pregnant woman class and labor complication in Tegal District.

\begin{tabular}{|c|c|c|c|c|c|c|c|c|}
\hline \multirow{3}{*}{ Independent Variables } & \multicolumn{4}{|c|}{ Complication of Labor } & \multirow{3}{*}{ OR } & \multicolumn{2}{|c|}{$95 \%$ CI } & \multirow{3}{*}{$\mathbf{p}$} \\
\hline & \multicolumn{2}{|c|}{ No } & \multicolumn{2}{|c|}{ Yes } & & \multirow{2}{*}{$\begin{array}{l}\text { Lower } \\
\text { Limit }\end{array}$} & \multirow{2}{*}{$\begin{array}{c}\text { Upper } \\
\text { Limit }\end{array}$} & \\
\hline & $\mathbf{n}$ & \% & $\mathbf{n}$ & \% & & & & \\
\hline \multicolumn{9}{|l|}{ Maternal age } \\
\hline$<20$ and $\geq 35$ years & 42 & 79.2 & 11 & 20.8 & 0.25 & 0.1 & 0.63 & 0.002 \\
\hline \multirow{2}{*}{\multicolumn{9}{|c|}{ Maternal parity }} \\
\hline & & & & & & & & \\
\hline$<3$ children & 18 & 58.1 & 13 & 41.9 & 1.78 & 0.72 & 4.43 & 0.210 \\
\hline$\geq 3$ children & 42 & 71.2 & 17 & 28.8 & & & & \\
\hline \multicolumn{9}{|l|}{ Maternal education } \\
\hline$<$ Senior High School & 39 & 59.1 & 27 & 40.9 & 4.85 & 1.31 & 17.88 & 0.11 \\
\hline $\begin{array}{l}\geq \text { Senior High School } \\
\text { Maternal occunation }\end{array}$ & 21 & 87.5 & 3 & 12.5 & & & & \\
\hline Employee & 49 & 75.4 & 16 & 24.6 & 0.26 & 0.09 & 0.68 & 0.005 \\
\hline Housewife & 11 & 44 & 14 & 56 & & & & \\
\hline \multicolumn{9}{|l|}{ Pregnant woman class } \\
\hline Not participated & 34 & 81 & 8 & 19 & 0.28 & 0.11 & 0.72 & 0.007 \\
\hline Participated & 26 & 54.2 & 22 & 45.8 & & & & \\
\hline
\end{tabular}

Table 3. The analysis result of multiple logistic regression of the study of association between pregnant woman class and complication of labor in Tegal District.

\begin{tabular}{lcccc}
\hline \multirow{2}{*}{ Independent Variables } & \multirow{2}{*}{ OR } & \multicolumn{2}{c}{ 95\% CI } & \multirow{2}{*}{ P } \\
\cline { 3 - 4 } & & Lower limit & Upper limit & 0.020 \\
Pregnant woman age 20-35 years & 0.26 & 0.08 & 0.81 & 0.060 \\
Parity $\geq 3$ children & 3.47 & 0.95 & 12.69 & 0.009 \\
Maternal education $<$ SHS & 8.58 & 1.70 & 43.33 & 0.012 \\
Work outside & 0.21 & 0.06 & 0.71 & \\
Participated in PWC & 0.35 & 0.12 & 1.05 & \\
N observation $=90$ & & & \\
-2 log likelihood = 82.98 & & & \\
Nagelkerke $\mathrm{R}^{2}=41.1 \%$ & & & \\
\hline
\end{tabular}

\section{DISCUSSION}

1. Association between maternal age and complication of labor.

There was an association between maternal age and complication of labor. Mothers aged 20 to 35 years had $1 / 4$ times lower risk of experiencing complication of labor than mothers aged $<20$ years or $\geq 35$ years $(\mathrm{OR}=$ $0.26 ; 95 \% \mathrm{CI}=0.08$ to $0.81 ; \mathrm{p}=0.020$ ).

Women who are pregnant at a highrisk age can cause complications for mother and baby. Too-young mothers who are less than 20 years of age have not had mature reproductive organ. The uterus condition is not able to get pregnant and give birth. Besides, too-old mothers who are more than 35 years of age are possibly experience obs- tetric complication due to the decrease of reproductive health. Mothers are also not able to push.

The association between maternal age and complication of labor was shown based on study conducted by Senewe (2004). This study showed that mothers who were less than 20 or more than 35 years of age experienced 1.3 times risks of getting complication of labor compared to mothers aged 2134 years. Women who are pregnant less than 20 years of age have higher risk of experiencing abortion, anemia, malnutrition, hypertension, pre-eclampsia and eclampsia (Oemarsari, 2008). 
2. Association between maternal parity and complication of labor.

The result of the study showed that there was an association between maternal parity and complication of labor (OR $=3.47$; $95 \%$ $\mathrm{CI}=0.95$ to $12.69 ; \mathrm{p}=0.060)$. Mothers with parity $\geq 3$ children had a 5.5 times greater risks of experiencing complication of labor than mothers with parity $<3$ children.

The association between maternal parity and complication of labor was shown based on study conducted by Oster (2012). The result of the study showed that maternal primiparous and grandemultiparous with $\geq 4$ children had 1.33 times risks of experiencing complication of labor compared to multipara of 2-3 children.

Mother who experienced pregnancy for the first time was a new matter, thus she was motivated to improve her health of her pregnancy. Besides, mother who had given birth more than one time assumed that she was experienced.

\section{Association between maternal edu- cation and complication of labor}

There was a strong positive association between maternal education and complication of labor. Mothers with low education level of Elementary and Junior High School had 8.5 times greater risk of complication of labor than mothers with high education level of Senior High School and college (OR = 8.58; $95 \% \mathrm{CI}=1.7$ to $43.33, \mathrm{p}=0.009$ ).

Education will affect the way of thinking in making a decision for someone to use health services. Mothers with higher education will make the knowledge about education better. Mothers with low education who have good facilities are not necessarily used. It is because mothers with low education do not care about health program, so they do not know the dangers might occur (Martaadisoebrata, 2005).

The association between maternal education level and complication of labor was shown based on study conducted by Silva et al., (2014). The result of the study showed that the low education level was one of the factors related to pre-eclampsia.

\section{Association between maternal oc- cupation and complication of labor}

There was an association between maternal occupation and complication of labor. Working mothers have 1/5 times lower risks of experiencing complication of labor than housewives $(\mathrm{OR}=0.21 ; 95 \% \mathrm{CI}=0.06$ to $0.71 ; \mathrm{p}=0.012)$.

The association between employment and complication of labor was also reported based on study conducted by Romlah (2009). This study showed that there was an important association between employment and maternal behavior in planning labor and prevention of complication. Mothers had nine times chances to behave positively compared to mothers who did not work.

\section{Association between the pregnant woman class and complication of labor}

There was an association between the pregnant woman class and complication of labor. Mothers who participated in pregnant woman class during pregnancy had o.35 times lower risk of experiencing complication labor than pregnant woman who did not participate in pregnant woman class $(\mathrm{OR}=0.35 ; 95 \% \mathrm{CI}=0.12$ to $1.05, \mathrm{p}=$ 0.061).

The benefit of pregnant woman class was also reported based on study conducted by Purworini (2012). The study showed that there was an increase which statistically significant about response of labor $(\mathrm{p}<0.001)$, response of pregnancy, knowledge of labor $(\mathrm{p}<\mathrm{0.001})$, knowledge of pregnancy $(\mathrm{p}<0.001)$, and maternal condition before and after participating in pregnant woman class. 
This study concludes that there is an association between complication of labor and maternal age $(\mathrm{OR}=0.26 ; 95 \% \mathrm{CI}=0.08$ to $0.81 ; \mathrm{p}=0.020)$, maternal parity $(\mathrm{OR}=$ $3.47 ; 95 \% \mathrm{CI}=0.95$ to $12.69 ; \mathrm{p}=0.060$ ), maternal education $(\mathrm{OR}=8.58 ; 95 \% \mathrm{CI}=1.7$ to $43.33 ; \mathrm{p}=0.009)$, maternal occupation $(\mathrm{OR}=0.21 ; 95 \% \mathrm{CI}=0.06$ to $0.71 ; \mathrm{p}=$ $0.012)$, and pregnant women class $(\mathrm{OR}=$ $0.35 ; 95 \% \mathrm{CI}=0.12$ to $1.05 ; \mathrm{p}=0.061$ )

\section{REFERENCE}

Central Java Health Office. (2014). Profil Kesehatan Provinsi Jawa Tengah tahun 2014.

Damarati, Pujiningsih Y (2012). Analisis tentang paritas dengan kejadian ketuban pecah dini pada ibu bersalin di RSUD Sidoarjo. Jurnal kebidanan Embrio (1): 36-41.

Depkes RI (2009). Pegangan Fasilitator Kelas Ibu Hamil Tahun 2009. Pegangan Fasilitator Kelas Ibu Hamil. Jakarta: Departemen Kesehatan RI.

Diana, Hadyana S, Handono B (2013). Analisis Faktor-faktor Yang berhubungan dengan Komplikasi Obstetri Ibu dan Bayi di Kecamatan Parongpong Kabupaten Bandung Barat. Fakultas Ilmu Kesehatan Masyarakat.

Dina D, Seweng A, Nyorong M (2013). Faktor Determinan kejadian perdarahan postpartum di RSUD Majene. Bagian Kesehatan Reproduksi Fakultas Ilmu Kesehatan Masyarakat Universitas

Edyanti DB, Indawati R (2014). Faktor pada ibu yang berhubungan dengan kejadian komplikasi kebidanan. Jurnal biometrika dan kependudukan, 3 (1): 1-7.

Ghojazadeh M, Azami AS, Mohammadi M, Vosoogh S, Mohammadi S, NaghaviBM (2013). Prognostic Risk Factors For Early Diagnosing of Preeclamsia in Nulliparas. Nigerian Medical Journal.

Hastuti PS, Nugroho HSW. Usnawati N (2011). Efektifitas pelatihan kelas ibu hamil untuk meningkatkan pengetahuan, sikap, keterampilan dan kunjungan Antenatal Care. ISSN. 2 (2): 2086-3098.

Minitry of Health (2011). Pedoman Pelaksanaan Kelas Ibu hamil. Jakarta: Direktorat Jenderal Bina Gizi dan KIA.

Morgan G, Hamilton C (2009). Obstetri dan Ginekologi. Jakarta: EGC

Mu'minatunnisa M, Santosa U, Sumarni I (2013). Kejadian Perdarahan Postpartum Ibu Bersalin Berdasarkan Karakteristik dan Penyebab Di RSUD Kota Bandung. Jurnal Pendidikan Bidan. ISSN: 2089-2225

Murti B (2013). Desain dan ukuran sampel untuk penelitian kuantitatif dan kualitatif di bidang kesehatan. Yogyakarta: Gadjah Mada University Press.

Nugroho T (2011). Buku ajar obstetri untuk mahasiswa kebidanan. Yogyakarta: Nuha Medika.

Nugroho T (2012). Patologi Kebidanan. Yogyakarta: Nuha Medika.

Osninelli (2007). Hubungan pendidikan prenatal melalui kelas ibu hamil dengan persalinan tenaga kesehatan di Kabupaten Tanah Datar Sumatera Barat. Fakultas Kesehatan Masyarakat Universitas Gajah Mada Yogyakarta.

Purwarini D (2012). Pengaruh Kelas Ibu Hamil Terhadap Pengetahuan dan Sikap Ibu dalam Kehamilan dan Persalinan di Wilayah Puskesmas Gurah Kabupaten Kediri. Surakarta: Universitas Sebelas Maret Surakarta. 2(6): $624-63$.

Redshaw M, Henderson J (2013). Fathers engagement in pregnancy and childbirth: evidence from a national sur- 
vey. BMC Pregnancy and Childbirth, 13(70), 1-15.

Romlah S (2009). Pengaruh Kelas Ibu Hamil Terhadap Perilaku dalam Perencanaan P4K di Kabupaten Garut Jawa Barat Tahun 2009. Fakultas Ilmu Kesehatan Masyarakat Universitas Indonesia

Senewe PF, Sulistiyowati N (2004). Faktorfaktor yang berhubungan dengan komplikasi persalinan tiga tahun terakhir di Indonesia (Analisis lanjut SKRT-Surkesnas 2001). Buletin Penelitian Kesehatan. 32(2): 83-91

Silva LM, Coolman M, Steegers, Jaddoe VWV, Mool HA, Hofman A, Macken- bach JP, Raat H (2008). Maternal educational level and risk of gestasional hypertension: The Generation $\mathrm{R}$ study. Journal of Human Hypertension, 22: 483-492.

Simarmata OS, Armagustini Y, Bisara D (2007). Determinan kejadian komplikasi persalinan di indonesia (Analisis Data Sekunder Survei Demografi dan Kesehatan Indonesia Tahun 2007). Jurnal Ekologi Kesehatan 11(1): 11-23. UNFPA (2004). Maternal mortality update 2005, delivery into good hands. New York: Safe Research study and impact. 